\title{
Dinâmica do Uso e Ocupação da Terra em Área de Expansão da Fronteira Agrícola no Baixo Curso do Rio Palmeiras, Estado do Tocantins
}

\author{
Dynamics of Land Use and Occupation in Areas of Expansion of the Agricultural Boundary in \\ the Palmeira's River Low Course, Tocantins State
}

\author{
Letícia Giuliana Paschoal ${ }^{1}$ D $\triangle$, Fernando de Morais ${ }^{2} \Delta$ \\ 1Universidade Federal do Tocantins, leticiagiulianapaschoal@gmail.com, \\ https://orcid.org/0000-0002-1488-5933 \\ 2Universidade Federal do Tocantins, morais@mail.uft.edu.br
}

Recebido (Received): 28/01/2019

Aceito (Accepted): 06/05/2019

\begin{abstract}
Resumo: O sistema socioeconômico impõe alterações à dinâmica do uso da terra. Assim, esse trabalho possui como objetivo analisar a dinâmica do uso e cobertura da terra, ao longo de 49 anos (1968-2017), no setor Sul da bacia hidrográfica do rio Palmeiras (TO), destacando elementos do sistema socioeconômico e suas relações com processos de alterações sobre a hidrografia e o relevo desenvolvido sobre litologias calcárias. O setor do baixo curso da bacia hidrográfica do rio Palmeiras foi selecionado como fragmento representativo das alterações ambientais regionais. Para a área foram realizados mapeamentos de uso e cobertura da terra (1968 e 2017) e geomorfológico (1968), ambos na escala 1:25.000, além de trabalhos de campo. Os resultados permitiram constatar alterações na hidrografia com a construção de represas para consumo d'água pelo gado e reservatórios para geração de energia por meio da criação de uma Pequena Central Hidrelétrica; diminuição das áreas de Cerrado, que ocupavam 77,46\% da área no ano de 1968 e passou a ocupar 22,65\% em 2017; além do aumento nas áreas destinadas à pastagem, que passou a ocupar $56,01 \%$ da área em 2017, face aos 0,09\% ocupados em 1968, sendo que essa ocorre de forma extensiva e em alguns setores, sobre relevos cársticos, que são aos poucos descaracterizados. Assim, pretende-se contribuir com discussões acerca dos controles impostos pelo sistema socioeconômico aos sistemas físicos em áreas de expansão agropecuária na região Norte do Brasil.
\end{abstract}

Palavras-chaves: Cartografia Temática; Alterações Ambientais; Bacia Hidrográfica; Carste; Cerrado; Pecuária.

\begin{abstract}
The socioeconomics system imposes alterations to the dynamics of land use and occupation. Therefore, this work aims to analyze the dynamics of land use and occupation, over 49 years (1968-2017), in the Southern sector of the Palmeira's River watershed, highlighting elements of the socioeconomic system and its relations with processes of change over the hydrography and the developed relief over limestone lithology. The low course sector of the Palmeira's River watershed has $446.84 \mathrm{~km} 2$ and it was selected as representative fragment of the regional environmental changes. For the area, mapping of land use and occupation (1968 and 2017) and geomorphological (1968) were performed, both on the 1:25,000; and fieldwork to validate of data. The results allowed the verification of changes in the region hydrography, with the construction of dams for cattle water consumption and for reservoirs for power generation through creation of a small hydroelectric plant; reduction of the savannah areas, which occupied 77,46\% of the area in the year 1968 and occupy 22,65\% in 2017; and increased pasture areas, which occupy 56,01\% of the area in 2017, compared to 0,09\% in 1968, that occurs extensively, and in some sectors, on karst relief, which are being demeaned little by little. Thus, this research enabled the supply of parameters for a general diagnostic of the changes occurred in the area, in addition to contributing with discussions regarding the controls imposed by the socioeconomic system to the physical systems in areas of agricultural expansion in the Northern Region of Brazil.
\end{abstract}

Keywords: Thematic Cartography; Environmental Changes; Watershed; Karst; Savannah; Livestock. 


\section{Introdução}

A economia brasileira se configura, desde o início de sua colonização até o fim da década de 1920, como sendo de base agrária (FURTADO, 2007; PRADO JR., 2011, 2014). Apesar de ter se tornado urbanoindustrial a partir de então, ainda se configura como um dos principais exportadores de produtos agrícolas do mundo (CASTRO, 2013; GIRARDI, 2008). De acordo com dados do IBGE (2018), referentes ao ano de 2014, a maior parte do dinamismo da produção no setor agropecuário é atribuída às regiões Centro-Oeste $(41,1 \%)$ e Sul $(37,7 \%)$, seguido pelas regiões Sudeste $(9 \%)$, Nordeste $(9 \%)$, e Norte $(2,7 \%)$. Segundo Oliveira (2003), cerca de $80 \%$ do valor das exportações agropecuárias do Brasil é obtido com base em apenas nove setores: soja $(21,7 \%)$, carnes $(20 \%)$, sulcroalcooleira $(18,2 \%)$, café $(7,9 \%)$, couro $(7,6 \%)$, fumo $(4 \%)$, sucos de frutas $(3,7 \%)$, produtos florestais $(1,5 \%)$ e algodão $(0,7 \%)$; sendo elas responsáveis por $73,4 \%$ de toda a área plantada no país.

Apesar da região Norte se constituir em área de interesse nacional e internacional ligada à preservação dos recursos naturais ali existentes, por abrigar em seu território parte considerável da Floresta Amazônica e, em grande extensão do estado de Tocantins, o Cerrado, essa região vem passando por uma grande pressão relacionada ao agronegócio, que tem expandido sua fronteira, sobretudo, da região Centro-Oeste e Nordeste em sua direção. Assim, as características socioeconômicas regionais estão sendo modificadas e, embora ajudem a transformar o Brasil em um dos principais produtores de commodities agrícolas do mundo, as atividades agrárias e a ocupação humana sobre o bioma Cerrado e na área de borda da Amazônia possuem como consequência o aumento do desmatamento e a alteração da paisagem, sobretudo, em áreas destinadas à plantação da soja e à criação do gado bovino (GIRARDI, 2008; MORAIS, 2013; SILVA e MORAIS, 2016; INPE, 2019).

A produção da soja é realizada em sistema de monocultura em estabelecimentos de médio e grande porte, com a finalidade de exportação, servindo de alimento para rebanhos principalmente em países desenvolvidos, e sua "cadeia produtiva é dominada por um pequeno grupo de empresas transnacionais, que dominam o sistema na produção, processamento e venda" (GIRARDI, 2008, p. 249). Já a pecuária, ocorre de forma extensiva em grandes latifúndios. Assim, o sistema predominante de produção de gado no Brasil ocorre de forma a integrar pequenas propriedades familiares às poucas e "grandes empresas do setor, o que caracteriza uma produção camponesa subordinada ao agronegócio, pois os produtores familiares não têm o controle do sistema" (GIRARDI, 2008, p. 250).

No estado do Tocantins, associado ao avanço de novas fronteiras agrárias, ocorre a ação predatória do material lenhoso destinado à produção de carvão, usado, sobretudo, na fase de secagem dos grãos de soja, milho e milheto, o que tem impactado severamente o Cerrado. Desta forma, a região Norte tem sido considerada ao mesmo tempo, terra de oportunidades e limitações, no qual a agropecuária possui papel de destaque na economia regional (CASTRO, 2013).

O bioma Cerrado, segunda maior região biogeográfica da América do Sul, permaneceu praticamente inalterado até a década de 1960. Mudanças significativas sobre esse bioma começaram a ocorrer a partir da década de 1970, incentivados por programas instituídos pelo Governo Federal de uso e ocupação da região central do Brasil. Esses programas impulsionaram a dinamização do setor agrário, transformando a área ocupada originalmente por esse bioma na mais importante área de expansão da fronteira agrícola brasileira na atualidade (BRASIL, 2013).

A expansão agropecuária sobre o Cerrado fez também aumentar o número da população que reside sobre essa região biogeográfica, além de fazer com que a demanda por energia elétrica aumentasse. Nesse sentido, a região do Cerrado possui enorme potencial para a instalação de hidrelétricas, por compreender em seu território as nascentes das bacias Tocantins-Araguaia e São Francisco, além de importantes afluentes que drenam suas águas para as bacias Amazônica e do Prata, o que confere à área, grande importância na geração de energia para abastecimento regional.

No estado do Tocantins, a expansão agrária tem ocorrido em muitos setores sobre embasamento de rochas calcárias, o que tem alterado rapidamente a paisagem natural na área. No cenário nacional, são recentes os esforços de pesquisadores relacionados a estudos do relevo cárstico sob a ótica da geomorfologia nessa região, que apresenta o maior potencial para a ocorrência de cavernas no estado (MORAIS, 2013; SILVA e MORAIS, 2016). Conforme destaca Morais (2013), algumas feições cársticas na área rural, como dolinas e fendas calcárias, vêm sendo utilizadas para a disposição de resíduos sólidos. Esse fato constitui assim, em um sério problema ambiental, sobretudo, por se tratar de depósitos sobre rochas que reagem facilmente à umidade e peso que por ventura possam ser alocados sobre ele, intensificando processos de erosão e contaminação do solo na área. 
Diante do exposto, esse trabalho possui como objetivo, analisar a dinâmica do uso e cobertura da terra no setor do baixo curso da bacia hidrográfica do rio Palmeiras, localizada no Sudeste do estado do Tocantins, tendo como base mapeamentos dos anos de 1968 e 2017, os quais permitiram identificar os principais elementos do sistema socioeconômico que operam na área e suas relações com processos de alteração na rede hidrográfica e em relevos desenvolvidos sobre litologias calcárias, no decorrer desses 49 anos. Com base no objetivo da pesquisa, têm-se a hipótese central de que as organizações espaciais são consequências da dinâmica dos ciclos do sistema socioeconômico, que por sua vez, promovem alterações na dinâmica do uso e cobertura da terra e consequentemente, sobre feições do relevo e hidrografia.

\section{2. Área de Estudo}

Esse setor foi escolhido por apresentar processos de transformação da paisagem em área de expansão da fronteira agrária, que em alguns trechos ocorre sobre rochas carbonáticas do Grupo Bambuí, comum em todo o sudeste do estado de Tocantins, onde se desenvolve "o maior conjunto de ocorrências calcárias favoráveis à presença de cavernas no Brasil” (KARMANN e SÁNCHEZ, 1979, p. 117).

A unidade de estudo selecionada para o desenvolvimento desta pesquisa é a bacia hidrográfica do rio Palmeiras, principal afluente da margem direita do rio Palma, situada no Sudeste do estado de Tocantins (Figura 1). Essa bacia possui 4.787,92 $\mathrm{km}^{2}$ de área, distribuída entre os $11^{\circ} 24^{\prime} 44^{\prime \prime}$ e $12^{\circ} 22^{\prime} 9$ " de Latitude Sul e $47^{\circ} 0{ }^{\prime} 8^{\prime \prime}$ e $46^{\circ} 4^{\prime} 44^{\prime \prime}$ de Longitude Oeste, e apresenta altitudes que oscilam entre $325 \mathrm{~m}$, próximo à foz do rio, e $900 \mathrm{~m}$, em sua área Norte e Nordeste. A área dessa bacia se distribui por quatro municípios: Dianópolis, Novo Jardim, Ponte Alta do Bom Jesus e Taipas do Tocantins (Figura 1). Esses municípios situam-se afastados dos médios e grandes centros urbanos e se tornam de difícil acesso principalmente em época de chuva. Juntas, essas cidades possuem aproximadamente 28.000 habitantes, sendo Dianópolis a principal cidade da região em termos de infraestrutura básica.

Diante da área total da bacia hidrográfica do rio Palmeiras, o setor de seu baixo curso (Figura 1), apresentando $446,84 \mathrm{~km}^{2}$, foi selecionado para a realização de mapeamentos na escala de análise 1:25.000, por se tratar de uma área representativa das alterações que ocorrem em toda a porção Sudeste do Estado de Tocantins.

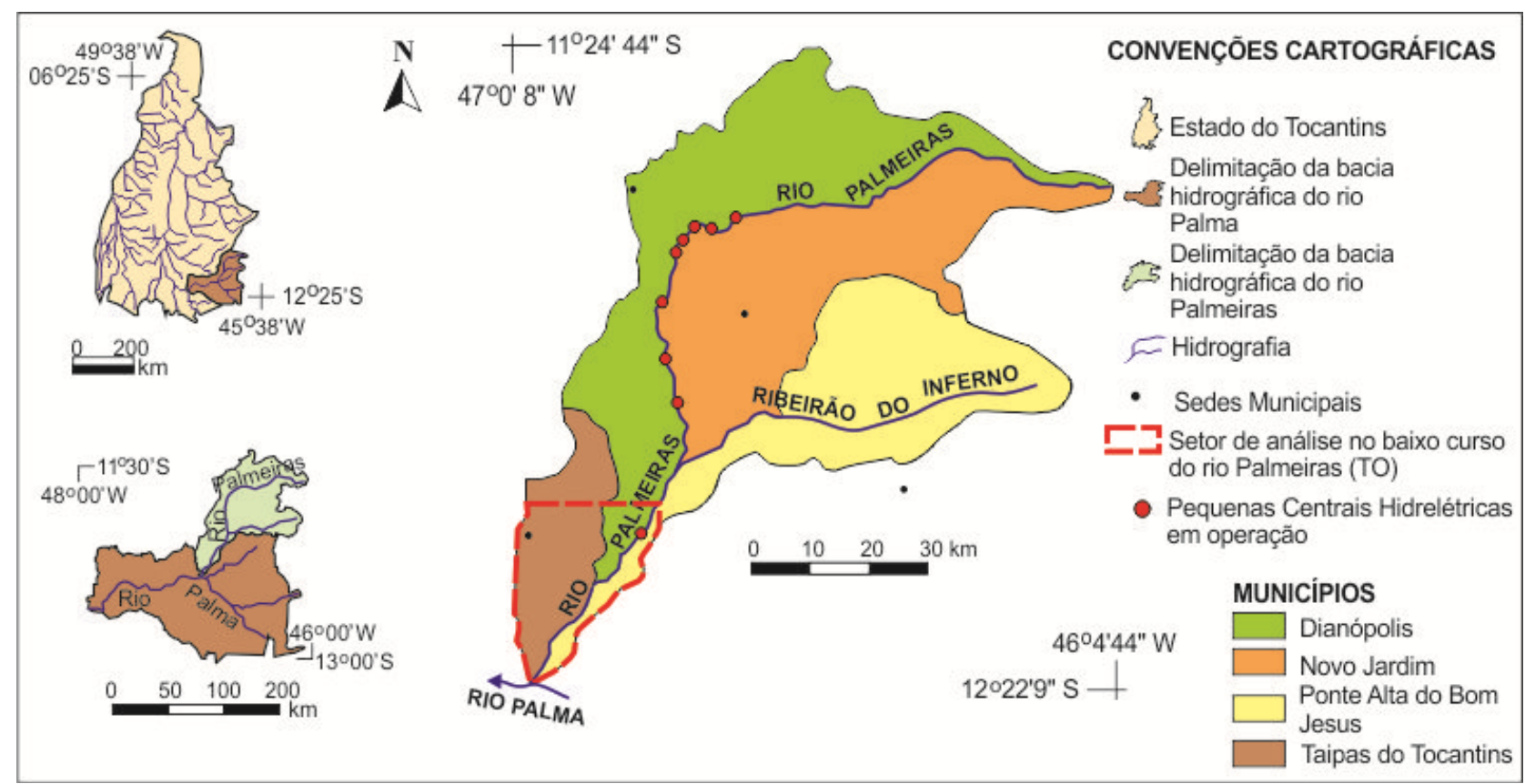

Figura 1: Localização da bacia hidrográfica do rio Palmeiras no interior do estado do Tocantins, com destaque para as áreas dos quatro municípios que essa bacia permeia e o setor de análise em seu baixo curso.

A bacia hidrográfica do rio Palmeiras se situa sobre a sub-bacia sedimentar Abaeté, inserida no contexto da Bacia Sedimentar Sanfranciscana, uma área de $140.000 \mathrm{~km}^{2}$, compreendida por registros sedimentares e vulcânico do Fanerozóico (ZALÁN e ROMEIRO-SILVA, 2007; KIANG e SILVA, 2015; CAMPOS e DARDENNE, 1997). Embora existam divergências bibliográficas sobre a hierarquia litoestratigráfica na região, esse estudo adotou a estratigrafia citada por Morais (2013), assim, sobre o embasamento cristalino pertencente ao complexo Almas-Cavalcante, da base para o topo na área de estudo, ocorrem as seguintes 
unidades geológicas sedimentares: Grupo Bambuí, composta predominantemente por rochas calcárias; Grupo Urucuia, constituído basicamente por arenitos de sistemas desérticos; e superficialmente, têm-se depósitos aluvionares, coluvionares e eluvionares recentes, pertencentes à Formação Chapadão, além de coberturas detrito-lateritica ferruginosas (CAMPOS e DARDENNE, 1997).

As nascentes do rio Palmeiras se localizam nas áreas de maior altitude, pertencentes a Serra Geral do Tocantins. Nesse setor, o rio apresenta característica de rio de planalto, vales abertos e pouco sinuosos, onde veredas se instalam (SANTOS, 2011). Na sequência, seu percurso apresenta vales encaixados e profundos, com sucessivas quedas e rápidos que permitem seu aproveitamento hidráulico com a finalidade de geração de energia (Figura 1).

O clima na bacia hidrográfica do rio Palmeiras é do tipo $\mathrm{C} 2 \mathrm{w} 2 \mathrm{~A}^{\prime} \mathrm{a}$ ': úmido e sub-úmido, sendo a precipitação média anual de $1.350 \mathrm{~mm}$ ao Leste e de $1.450 \mathrm{~mm}$ ao Oeste da bacia, e a temperatura média do ar é de $26{ }^{\circ} \mathrm{C}$ ao Noroeste e $25{ }^{\circ} \mathrm{C}$ no restante da bacia (SEPLAN, 2012). Diante desse cenário, a bacia do rio Palmeiras apresenta vegetação característica do bioma Cerrado e, áreas restritas apresentam vegetação da Floresta Estacional, condicionada pelas duas estações climáticas do ano: o verão extremamente úmido, seguida por estiagem acentuada de inverno, que provoca a queda das folhas (SEPLAN, 2012).

\section{Metodologia}

A análise das alterações no uso e cobertura da terra do baixo curso da bacia hidrográfica do rio Palmeiras e suas relações com processos de alterações sobre a hidrografia e o relevo desenvolvido sobre litologias calcárias, foi possível a partir dos procedimentos descritos a seguir.

\subsection{Mapas de Uso e Cobertura da Terra (1968 e 2017)}

A elaboração do mapa de uso e cobertura da terra do ano de 1968, ocorreu com base na interpretação de 8 fotografias aéreas (numeração 8312, 8313, 8314, 8315, 2735, 2736, 2737 e 2739), do mês de Agosto do ano supracitado, na escala aproximada de 1:45.000, adquiridas junto à Companhia de Pesquisa de Recursos Minerais (CPRM) - Serviço Geológico do Brasil, e na interpretação de 3 imagens do satélite RapidEye (números 2333506, 233406 e 233405), do ano de 2014, que compuseram um mosaico da área a ser interpretada. As imagens RapidEye foram adquiridas por meio da Divisão de Geração de Imagens do Instituto Nacional de Pesquisas Espaciais (DGI/INPE). A resolução espacial dessas imagens é de 5m e suas tomadas foram realizadas entre os meses de Março e Junho do ano de 2014.

As fotografias aéreas, em formato digital, possuindo $300 \mathrm{dpi}$, foram georreferenciadas com base em informações distribuídas entre seis cartas topográficas: Dianópolis (Folha SC.23-Y-C-VI MI-1832) e Taipas (SD-23-V-A-III), executadas pelo Ministério do Exército, Diretoria de Serviço Geográfico (1979), datum horizontal Córrego Alegre (MG) e vertical de Imbituba, SC; e Rio da Conceição (SC.23-Y-C-III MI-1775), Rio do Santo (SC.23-Y-C-I MI-1776) IBGE, Rio Palmeiras (SC.23-Y-D-IV) IBGE e Taguatinga (SD-23-VB-I) IBGE, executadas pela Secretaria de Planejamento da Presidência da República (1980), datum horizontal SAD-69 e vertical de Imbituba, SC. As cartas apresentam escala 1:100.000, equidistância entre as curvas de nível de 50m e permitiram delimitar a bacia hidrográfica em análise, com base na qual gerou-se o mosaico da área de estudo.

O procedimento operacional adotado para gerar os polígonos de uso e cobertura da terra ocorreu de forma manual e foi realizado diretamente na tela do computador, resultando em mapas dos anos de 1968 e 2014, na escala 1:25.000. Com relação ao cenário mais recente, os dados foram reambulados em campo, no ano de 2017, permitindo averiguação in loco das dúvidas ocorridas durante o processo, bem como a atualização de suas classes de uso e cobertura.

O uso e cobertura da terra foi identificado a partir da interpretação de modelos, tonalidades, formas, texturas, arranjo espacial das atividades e localização no terreno, e as classes estabelecidas visam atender às necessidades do cenário brasileiro, conforme sugere o IBGE (2013). Assim, essas foram estabelecidas da seguinte maneira: As classes de nível I, terra e água, respectivamente, foram mantidas de acordo com as orientações do manual do IBGE (2013). A classe de nível II e suas respectivas subclasses (nível III e IV) foram subdivididas de acordo com as especificidades da área em: - lagoas e reservatórios artificiais; - áreas antrópicas não agrícolas (residências rurais e mineração), - áreas antrópicas agrosilvopastoris (cultivo temporário, silvicultura, pasto antrópico limpo, pasto antrópico sujo, pasto nativo limpo e pasto nativo sujo); - e área de vegetação natural (Formação campestre: campo sujo e campo limpo; Formação savana: Cerrado ralo, Cerrado típico e Cerrado denso). 


\subsection{Mapa Geomorfológico (1968)}

A elaboração do mapeamento geomorfológico da área, na escala 1:25.000, buscou orientação na proposta de Tricart (1965), a qual afirma que este tipo de mapeamento deve comportar quatro tipos de informações de naturezas diferentes, a saber: morfometria, morfografia, morfogênese e cronologia.

Os dados morfométricos representam valores quantitativos e foram representados por meio das curvas de nível e cotas altimétricas. Com a finalidade de representar diferentes feições topográficas, as informações morfográficas foram obtidas a partir da interpretação de pares estereoscópicos de fotografias aéreas do ano de 1968. Os elementos relacionados à morfogênese encontram-se associados aos símbolos utilizados na morfografia, que além das formas indicam o agente responsável por sua origem. Elementos referentes à cronologia foram representados parcialmente, por meio da interpretação dos dados que compõem a carta geológica, o que permitiu identificar o tipo de litologia que aflora na área de estudo, além de remeter ao período em que se formaram as rochas que dão sustentação ao relevo.

Encontra-se no setor da bacia hidrográfica em análise, inserido no grupo feições estruturais, alguns patamares estruturais. Os dados litológicos, advindos da interpretação do mapa geológico, foram representados por diferentes níveis de cinza de acordo com o grau de resistência ao intemperismo do tipo de rocha predominante dentro de cada formação, diferentemente do proposto por Tricart (1965), o qual sugere que a área de determinada litologia seja mapeada com hachuras verticais dispostas com maior ou menor proximidade entre si de acordo com a resistência da rocha ao intemperismo. Essa adaptação foi realizada com a finalidade de propiciar uma maior legibilidade das cartas geomorfológicas, evitando a sobreposição de hachuras e simbologias utilizadas no mapeamento.

As simbologias que compõem a legenda se pautaram principalmente na adaptação das propostas de Tricart (1965) e Verstappen e Zuidan (1975). As formas de relevo foram identificadas por meio da estereoscopia digital. Para tanto, pares de fotografias aéreas, de numeração 8312, 8313, 8314, 8315, 2735 , 2736, 2737, 2738 e 2739, do ano de 1968, foram transformados em sete imagens anáglifos tridimensionais, obtidas por meio do aplicativo StereoPhoto Maker, seguindo as orientações de Souza e Oliveira (2012) e complementadas por Paschoal e Morais (2017). Essas imagens foram georreferenciadas por meio da interface ArcMap e sua interpretação e vetorização ocorreu diretamente na tela do computador, conforme as orientações técnicas de Paschoal et al. (2010).

\section{Resultados e Discussão}

Obteve-se como resultados relacionados ao baixo curso do rio Palmeiras, os mapas de uso e cobertura da terra dos anos de 1968 e 2017 (Figura 2), que forneceram os dados quantitativos que compõem o gráfico da Figura 3. Esses dados, associados aos obtidos por meio do mapeamento geomorfológico do ano de 1968 (Figura 4) e análises realizadas em campo no ano de 2017, permitiram, de maneira geral, inferir a evolução da dinâmica do uso e cobertura da terra, e diagnosticar alterações sobre alguns setores do relevo e hidrografia, sob interferência antrópica.

Os dados de 1968 (Figuras 1 e 2) correspondem à fase anterior a uma grande parte das terras na área do baixo curso do rio Palmeiras serem destinadas a atividades agrária e pecuária, ocorrendo o predomínio da vegetação natural ligada ao Cerrado. Desta forma, o mapa geomorfológico de 1968 (Figura 4) foi adotado como representativo do cenário geomorfológico original da área, correspondente à fase anterior a existência de significativas atividades antrópicas. Dados mais recentes sobre o relevo foram obtidos por meio de trabalho de campo realizado no ano de 2017 e são representativos de uma fase de perturbação ativa, no qual o sistema socioeconômico se impõe aos físicos. 


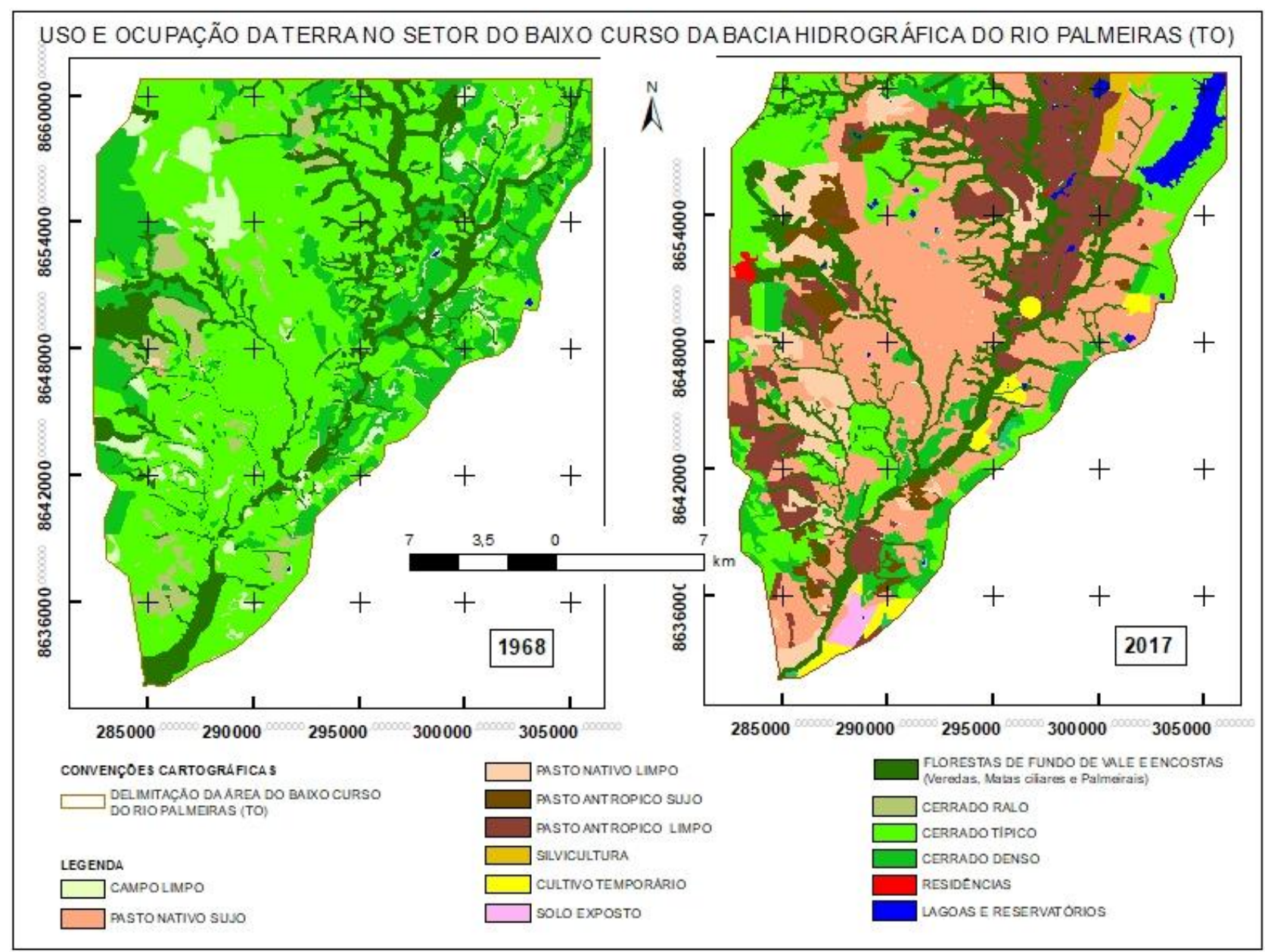

Figura 2: Uso e cobertura da terra no setor do baixo curso do rio Palmeiras (TO), no ano de 1968 e 2017.

Os dados de 1968 (Figura 2) permitem constatar que os usos da terra mais expressivos eram constituídos de Cerrado típico $(55,12 \%)$, Cerrado denso $(17,93 \%)$ e florestas de fundo de vale e encostas (Veredas, Matas ciliares e Palmeirais) $(16,75 \%)$, seguidos pelas classes campo limpo $(5,2 \%)$ e Cerrado ralo $(4,41 \%)$, solo exposto $(0,46 \%)$, pasto nativo limpo $(0,05 \%)$, pasto nativo sujo $(0,04 \%)$ e lagoas e pequenas represas $(0,04 \%)$.

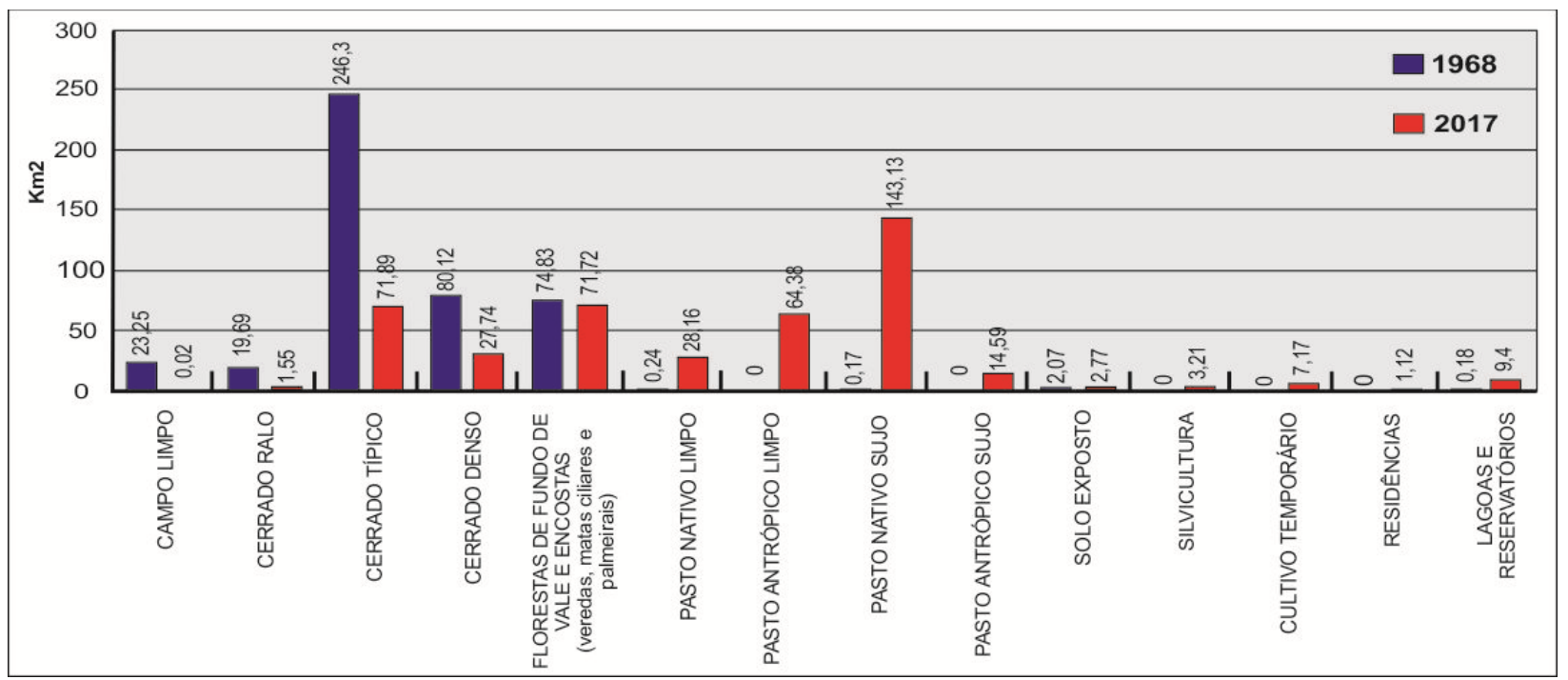

Figura 3: Área ocupada por distintas classes de uso e cobertura da terra no baixo curso da bacia hidrográfica do rio Palmeiras nos anos de 1968 e 2017. 


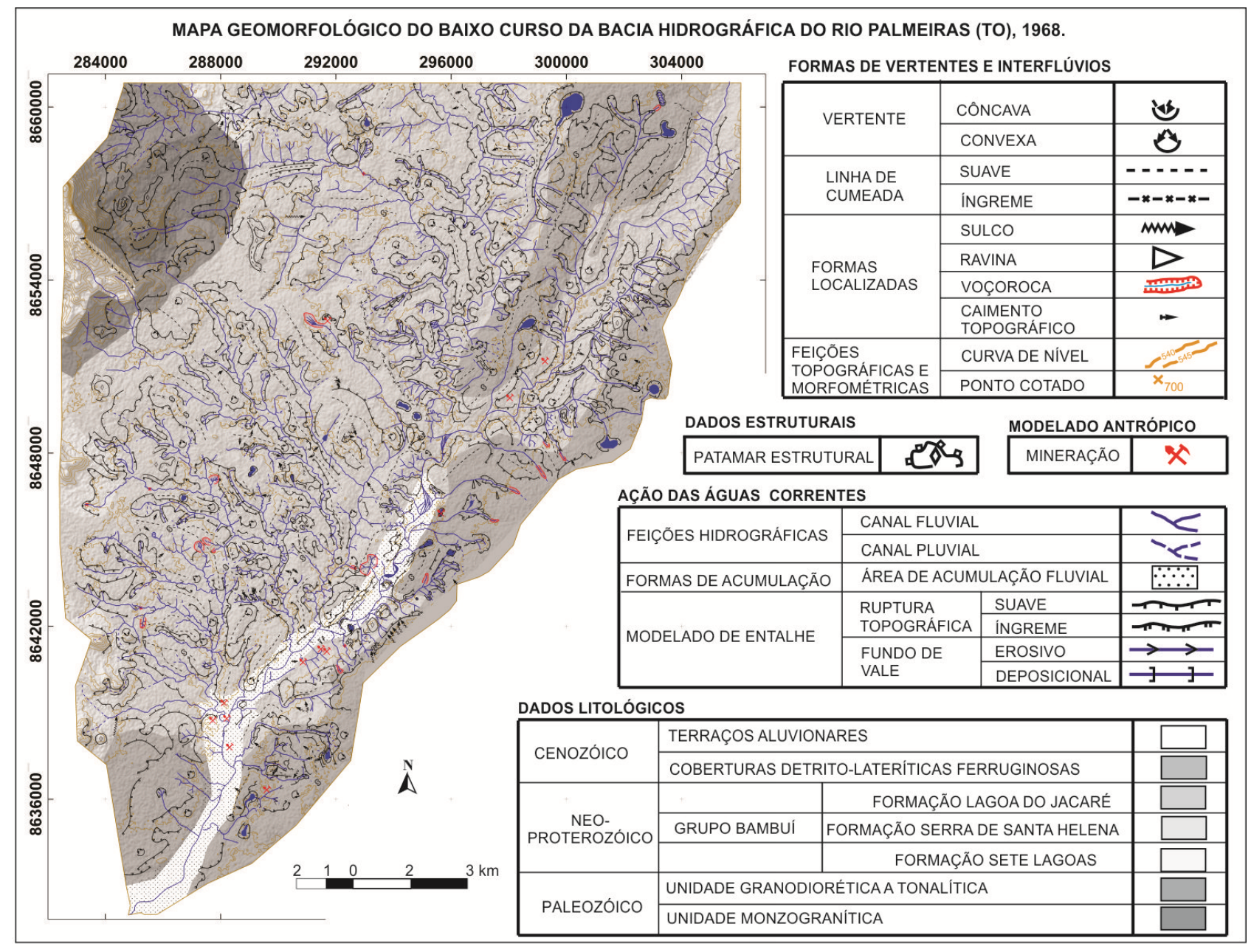

Figura 4: Mapa geomorfológico, representativo do relevo original (1968), do baixo curso do rio Palmeiras (TO).

Neste período, constatou-se que os usos da terra destinados à pastagem ocorriam de forma restrita, denotando o caráter de sua criação para a subsistência. Outra característica é o fato da criação do gado ocorrer de forma extensiva sobre áreas de vegetações nativas. Assim, foi possível diferenciar duas classes de pastagem nesse período: A classe denominada "pasto nativo limpo", caracterizado pela presença do gado que pastoreia livremente sobre a vegetação natural que compreende as classes de uso e cobertura da terra: campo limpo ou Cerrado ralo; e a classe "pasto nativo sujo", que reproduz a mesma situação, porém, ocorre sobre as classes: Cerrado típico e Cerrado denso.

O Cerrado é descrito por Ribeiro e Walter (1998) como sendo uma estrutura savânica, caracterizada por uma vegetação rasteira predominantemente herbácea e por uma cobertura lenhosa. Quando essa cobertura lenhosa varia de 5 a 20\%, têm-se o Cerrado ralo (savana parque), que se desenvolve nas planícies inundáveis do estado; entre 20 e 50\%, têm-se o Cerrado típico (savana arborizada, também denominada de Cerrado rupestre), que se desenvolve sobre afloramentos rochosos; e entre 50 e 70\%, têm-se o Cerrado denso (savana florestada ou cerradão) (RIBEIRO E WALTER, 1998). Desta forma, a classificação desses usos da terra foi realizada de acordo com a fitofisionomia da vegetação observada nas fotografias aéreas do ano de 1968, e totalizaram juntas $77,46 \%$ da área no setor. O mapa de uso desse ano (Figura 2) permite constatar que a espacialização do Cerrado típico ocorre originalmente por toda a área da bacia, sobretudo, nos interflúvios das porções Norte e Sul, e em áreas de fundo de vale e interflúvios na região central. Glebas do Cerrado denso se destacavam nos setores Leste e Oeste, entremeados pelo Cerrado típico. Pequenas manchas de Cerrado ralo aparecem nas porções Sul, Leste e Norte da área, sempre próximos a áreas ocupadas pelo Cerrado típico e corpos hídricos.

Em geral, na área de estudo, as formações vegetais de fundo de vale são compostas por veredas, palmeirais e matas ciliares. Diante da escala das fotografias aéreas utilizadas para a construção do mapa de uso e cobertura da terra, essas categorias foram mapeadas em conjunto, totalizando 16,75\% da área no setor. De acordo com a EMBRAPA (2017c), as veredas ocorrem estritamente em áreas onde o lençol freático aflora e são marcadas pela presença das palmeiras arbóreas Mauritia Flexuosa (Buriti) em meio a agrupamentos de espécies arbustivo-herbáceas. Nas veredas, as copas dos Buritis não se tocam de forma 
contínua como nos butitizais. Os palmeirais se caracterizam pela presença de um único tipo de palmeira arbórea, sendo os mais comuns, a Macaúba (Acrocomia aculeata), a Gueroba ou Guariroba (Syagrus oleracea) e o Babaçu (Attalea speciosa) (EMBRAPA, 2017a). É a existência expressiva desse tipo de formação vegetal no entorno do rio, que o faz receber o nome Rio Palmeiras. A mata-ciliar acompanha grande parte das margens do Rio Palmeiras, que por possuir um leito expressivo, impede que as copas das árvores de ambas as margens se toquem.

Outro tipo de vegetação natural que aparece em 1968, e ocupa 5,2\% da área, distribuída em pequenas parcelas do solo no setor Oeste e próximo a algumas nascentes no setor Leste, é a de campo limpo, caracterizada por uma vegetação predominantemente herbácea-rasteira, com raros arbustos e ausência total de árvores (EMBRAPA, 2017b).

Ao analisar o mapa geomorfológico do setor do baixo curso do rio Palmeiras, no ano de 1968 (Figura 4), constata-se o predomínio de existência de rupturas abruptas na paisagem. As rupturas topográficas marcam a evolução da vertente, ou seja, evidenciam que ao longo desta há um processo erosivo diferenciado. Por se tratar de um cenário representativo do relevo original, essas feições possuem origem em fatores naturais, tais como em regiões onde há contato entre diferentes materiais que compõem a litologia ou em áreas de contato entre diferentes tipos de vegetações.

Outras formas indicativas de processos erosivos a serem considerados no baixo curso do rio Palmeiras, constituem-se na existência de sulcos erosivos e ravinas, situados, na maior parte dos casos, próximo aos canais fluviais. Os sulcos marcam o estágio inicial de processos erosivos lineares sobre as vertentes, que podem evoluir para ravinas, e em seu estágio mais avançado, culminar em uma voçoroca, feição essa observada no entorno de diversas cabeceiras de drenagem no ano de 1968 (Figura 4). Assim como no caso das rupturas topográficas, mediante o confronto entre a espacialização do uso e ocupação da terra (Figura 2) e da localização dos sulcos e voçorocas (Figura 4), é possível constatar que essas feições possuem uma evolução natural e repercutem pontos de fragilidade do relevo, onde formações de superfície são menos consolidadas.

O mapa geomorfológico (Figura 4) também permitiu constatar que a dinâmica que predomina no alto curso dos canais fluviais, próximo às suas nascentes, é erosiva. Esses setores apresentam vales mais encaixados nas concavidades do relevo e declividades mais elevadas se comparado com comportamento do rio próximo à sua foz, onde a altimetria e a declividade são menores, o que faz com que o rio apresente uma dinâmica predominantemente deposicional.

Diante da comparação da rede hidrográfica entre os anos de 1968 e 2014 (Figura 5), associado ao trabalho de campo realizado no ano de 2017, foi possível verificar alterações morfohidrográficas associadas, sobretudo, à criação de diversos represamentos e reservatórios no leito do rio. Conforme salienta Penteado (1978), a construção de reservatórios ao longo do curso do rio faz com que ele modifique "seu leito por erosão e deposição, para estabelecer o equilíbrio entre a energia e a resistência". Fato esse que comprova a formação de um relevo antropogênico, no qual a humanidade se torna responsável pela esculturarão da paisagem por meio da imposição de mecanismos de controle aos processos naturais.

A obra de engenharia empregada na construção da barragem faz com que, na área do reservatório, além da água, acumule-se uma quantidade maior de sedimentos. Esse acúmulo de sedimentos na área inundada promove uma alteração na forma do relevo do fundo do leito, que leva a uma quebra de energia da água que vem do montante e ao passar por ali, diminui sua velocidade, promovendo um maior depósito de sedimentos. Ao mesmo tempo, a erosão remontante ganha uma nova dinâmica, na tentativa de estabelecimento de um novo perfil de equilíbrio para esse setor do rio. Ao passar pelas comportas do reservatório, devido ao desnível topográfico, essa água carregada de sedimentos, adquire alta velocidade, erodindo o leito do rio à jusante, que também terá o seu perfil de equilíbrio alterado.

A classe de uso e cobertura da terra denominada lagoas e reservatórios, no ano de 2017, passou a ocupar 2,1\% da área, frente aos 0,04\% ocupados no ano de 1968 (Figura 3). Esse aumento está relacionado ao alagamento de uma ampla área no Nordeste desse setor da bacia, vinculado ao represamento da água para funcionamento da Pequena Central Hidrelétrica $(\mathrm{PCH})$ Lagoa Grande e à construção de pequenas represas em área de pastagem, com a finalidade de fornecimento de água para o gado (Figuras 2 e 5). Em trabalho de campo, realizado em período de estiagem, constatou-se que na área da bacia do rio Palmeiras, grande parte das lagoas e dos canais fluviais que as abastecem possuem regime intermitente, conforme retratado na Figura 6, onde o leito da lagoa, situada nas proximidades da Latitude $12^{\circ} 19^{\prime} 6^{\prime \prime} \mathrm{S}$ e Longitude $46^{\circ} 54^{\prime} 54^{\prime \prime} \mathrm{W}$, apresenta-se parcialmente seca. Nessa, uma pequena lâmina d'água serve como uma das últimas alternativas naturais de obtenção de água pelo gado na propriedade. Com relação à PCH Lagoa Grande, essa entrou em operação no ano de 2008, possui um potencial hidrelétrico instalado de $25,6 \mathrm{~mW}$, e faz parte de um 
complexo hidrelétrico, junto com outras oito PCHs instaladas ao longo do curso do rio Palmeiras (TO)

(Figura 1), que possibilita o fornecimento de energia na região de acordo com a crescente demanda.

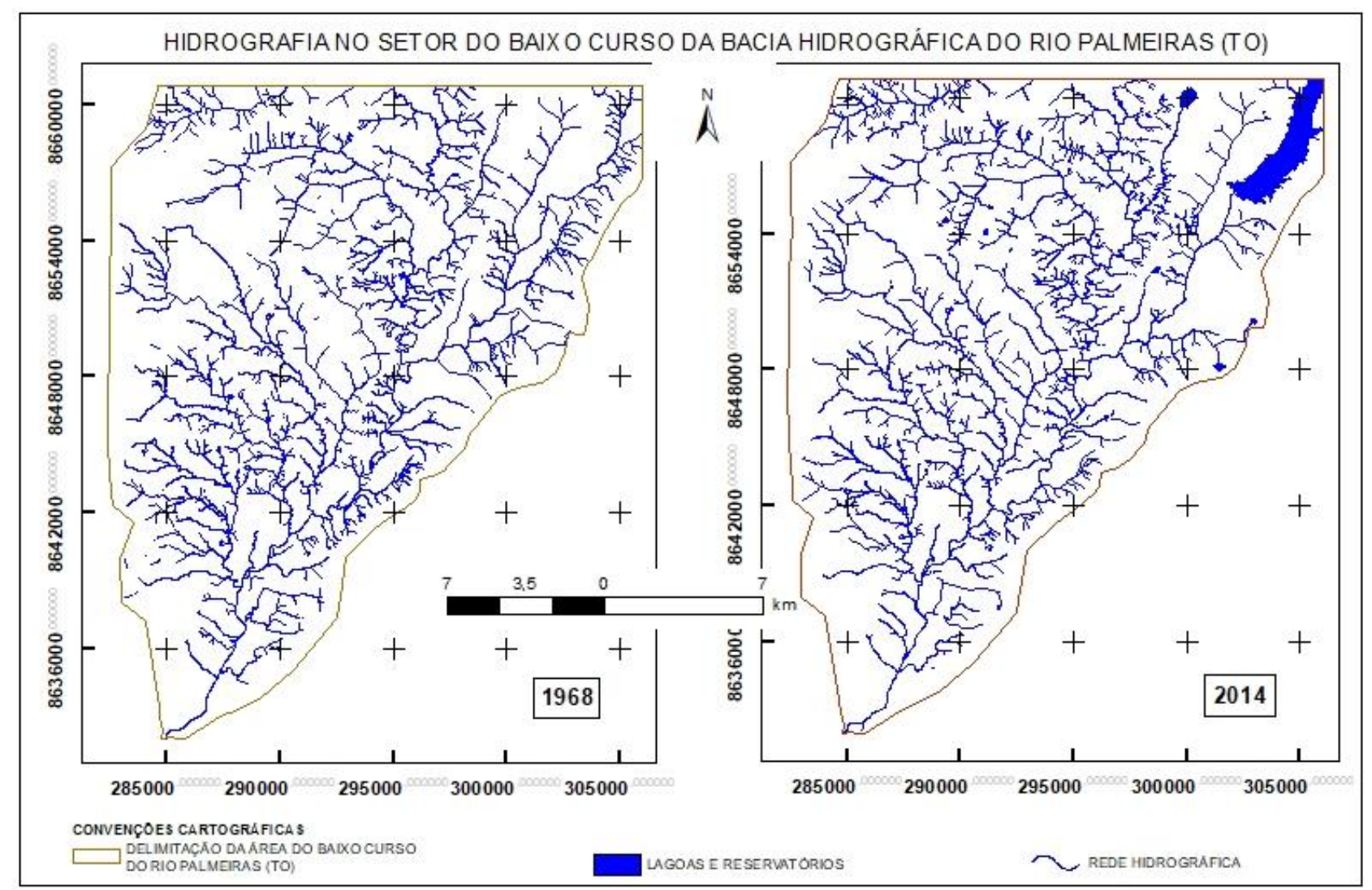

Figura 5: Rede hidrográfica do baixo curso do Rio Palmeiras (TO) nos anos de 1968 e 2014, obtidas por meio da interpretação de fotografias aéreas e imagens obtidas por meio do satélite RapidEye, respectivamente.

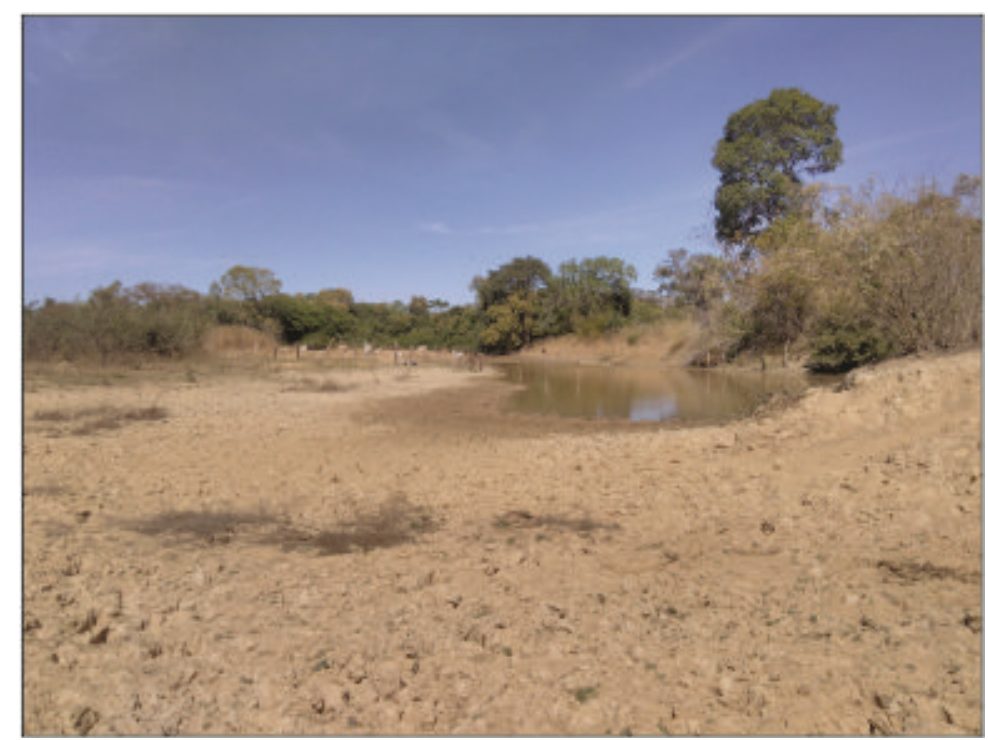

Figura 6: Leito de lagoa parcialmente seca em época de estiagem no baixo curso da bacia hidrográfica do Rio Palmeiras.

No ano de 2017, constatou-se o surgimento de outras classes de uso e cobertura da terra vinculadas à ação antrópica na área (Figuras 2 e 3), que denotam o avanço da fronteira agrária da região Centro-Oeste em direção à região Norte do país. Desta forma, a classe de uso e cobertura da terra denominada Cerrado típico foi a mais impactada, apresentando $16,9 \%$ do uso e cobertura da terra no baixo curso da bacia, face aos $55,12 \%$ da área ocupada, em 1968. As classes de uso e cobertura da terra: Cerrado denso e Cerrado ralo também tiveram suas áreas reduzidas no cenário de 2017, passando a ocupar $6,21 \%$ e $0,35 \%$ da área, 
respectivamente. Já a classe de uso campo limpo praticamente deixou de ser observada nesse domínio, ocupando apenas $0,02 \mathrm{~km}^{2}$ de área.

Em detrimento da redução areal ocupada pelas classes de uso e cobertura da terra supracitadas, outras surgiram, sobretudo, as vinculadas às atividades pecuárias. Desta forma, as classes pasto nativo limpo (Figura 7a) e sujo (Figura 7b) passaram a ocupar 6,3\% e 32,03\% da área (Figura 3), e os pastos antrópico limpo e sujo, 14,41\% e 3,27\%, respectivamente (Figura 3).
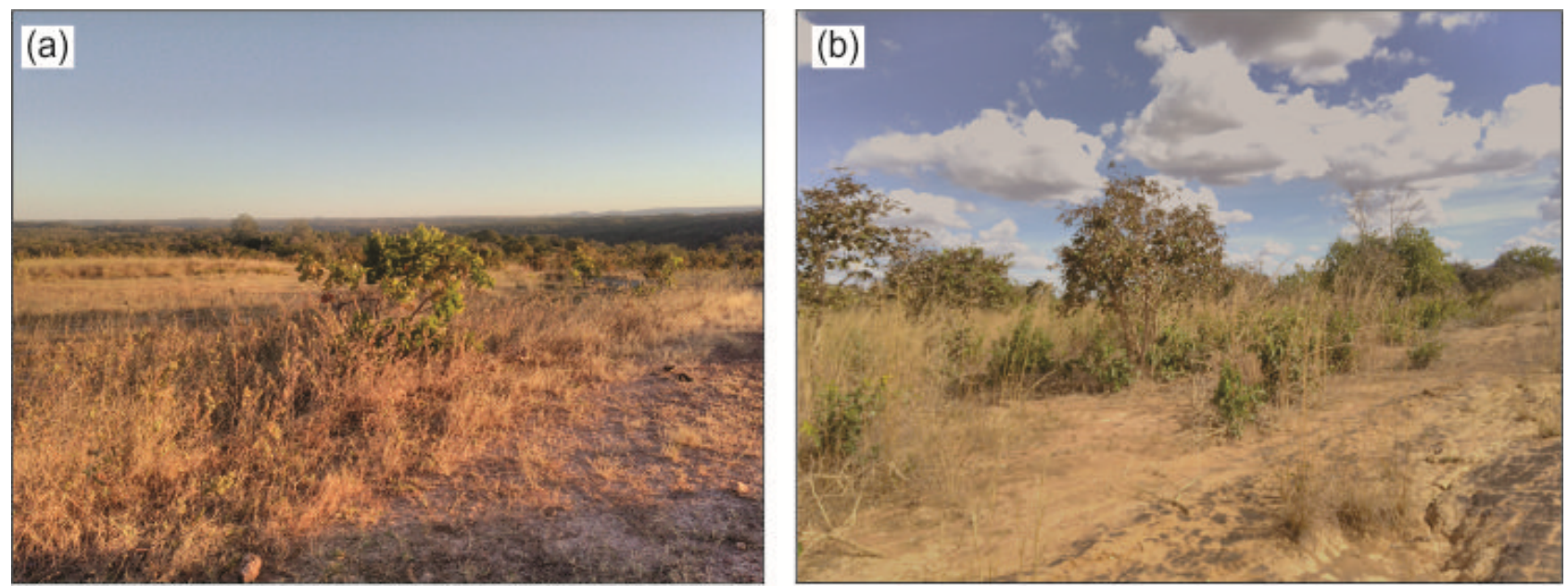

Figura 7: (a) Pasto nativo limpo sobre área anteriormente classificada como campo sujo. (b) Pasto nativo sujo sobre área anteriormente classificada como Cerrado típico.

A vegetação classificada como "pasto antrópico" possui característica predominantemente de gramínea e/ou gramínea intercalada com gêneros arbustivos. No geral estas áreas não apresentam características de vegetação de pastagem natural, tendo sido introduzidas pela intervenção antrópica. Esta categoria foi subdivida em duas subcategorias: pasto antrópico limpo, caracterizado por vegetação de porte predominantemente rasteiro (Figura 8a); e pasto antrópico sujo, o qual apresenta junto à vegetação gramínea, alguns gêneros arbustivos que se estabeleceram de forma espaçada no terreno, e pode estar relacionado à falta de manutenção das áreas por parte de seus proprietários (Figura $8 b$ ). A divisão entre estas duas subcategorias é tênue e baseou-se em aspectos visíveis da vegetação que recobre a terra.
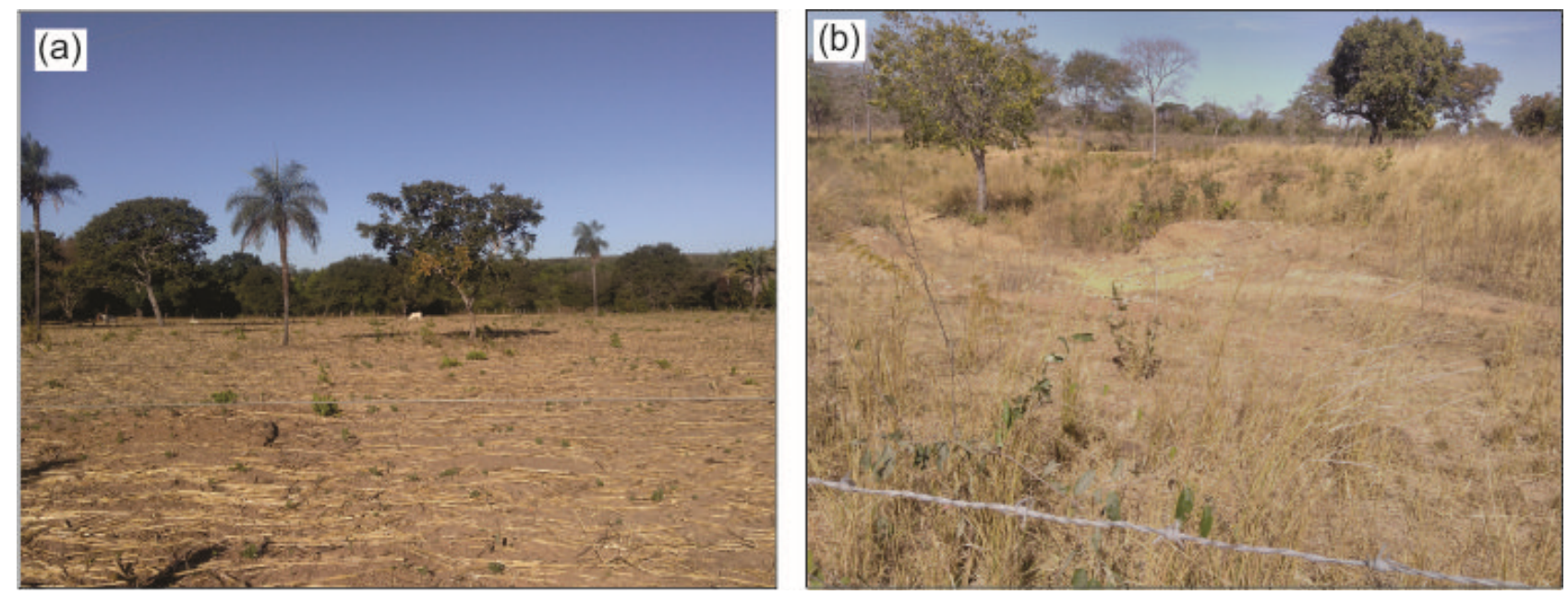

Figura 8: (a) Pasto antrópico limpo em primeiro plano na imagem. (b) Setor de pasto antrópico sujo.

Foi nessas áreas destinadas a atividades de pastagens no baixo curso da bacia hidrográfica do Rio Palmeiras que se identificou, em trabalho de campo, a presença de relevos cársticos. O mapeamento geomorfológico realizado na escala 1:25.000, para o ano de 1968, não possibilitou identificá-lo, pois, além da escala dos pares de fotografias aéreas usados na fotointerpretação, muitas vezes o carste, vinculado às rochas do Grupo Bambuí, apresentam-se encobertos pela vegetação natural (Figura 9a) ou então, passam a fazer parte de áreas destinadas à pastagem e o sobrepastoreio ocorre sobre ela, ajudando a descaracterizá-las (Figuras $9 \boldsymbol{b}$ e $9 \boldsymbol{c}$ ). De acordo com Rodrigues et al. (2007, p.114), o modelado cárstico é considerado um 
"[...] conjunto de formas originadas predominantemente por processos de dissolução das rochas na água, em sequência de uma permeabilidade elevada e de um soerguimento significativo", sendo que em superfície predominam depressões fechadas ou relevos residuais de dissolução e em profundidade há o predomínio de grutas, onde ocorre a circulação de água
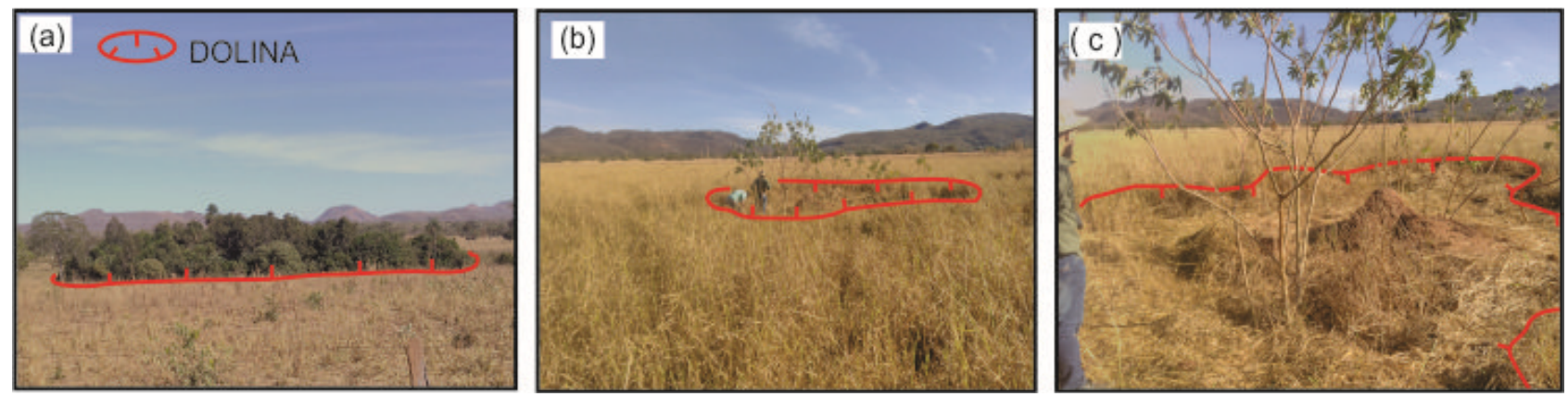

Figura 9: $(\boldsymbol{a})$ - Vegetação característica de pasto nativo limpo, com destaque para a dolina encoberta por vegetação arbórea, no centro da imagem. O desenvolvimento arbóreo denso é típico de áreas com elevada umidade, o que permite inferir que em seu interior ocorre a presença de água. Área próxima às coordenadas

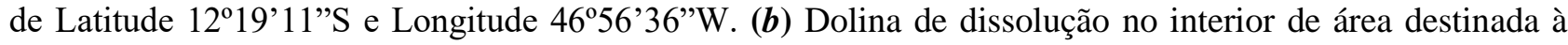
pastagem nas proximidades da Latitude $12^{\circ} 12^{\prime} 15^{\prime}$ 'S e Longitude $46^{\circ} 59^{\prime} 33^{\prime \prime} \mathrm{W}$. (c) Detalhes do interior da dolina de dissolução impactada pelo sobrepastoreio.

O desenvolvimento do relevo cárstico no setor do baixo curso do rio Palmeiras foi constatado, sobretudo, por meio da presença de dolinas. As dolinas são consideradas formas por excelência do modelado cárstico, caracterizadas por uma depressão superficial fechada, de expressividade horizontal maior do que sua profundidade, de formato circular, elíptica ou assimétrica, podendo alcançar dezenas de metros (RODRIGUES et al., 2007).

As dolinas encontradas na área possuem em sua maioria, característica de dolinas formadas pelo processo de dissolução superficial. Rodrigues et al. (2007, p.62) definem o processo de dissolução como uma erosão químico ou físico-químico "que conduz à dissolução das rochas por ação da água. [...] A água carregada de ácido carbônico promove a dissolução através da passagem do carbonato de cálcio (relativamente insolúvel) a bicarbonato de cálcio (solúvel)". Em menor quantidade, verificou-se a ocorrência de dolinas de colapso (Figura 10a), que possui gênese principal relacionada ao abatimento do teto de uma galeria subterrânea (RODRIGUES et al., 2007).
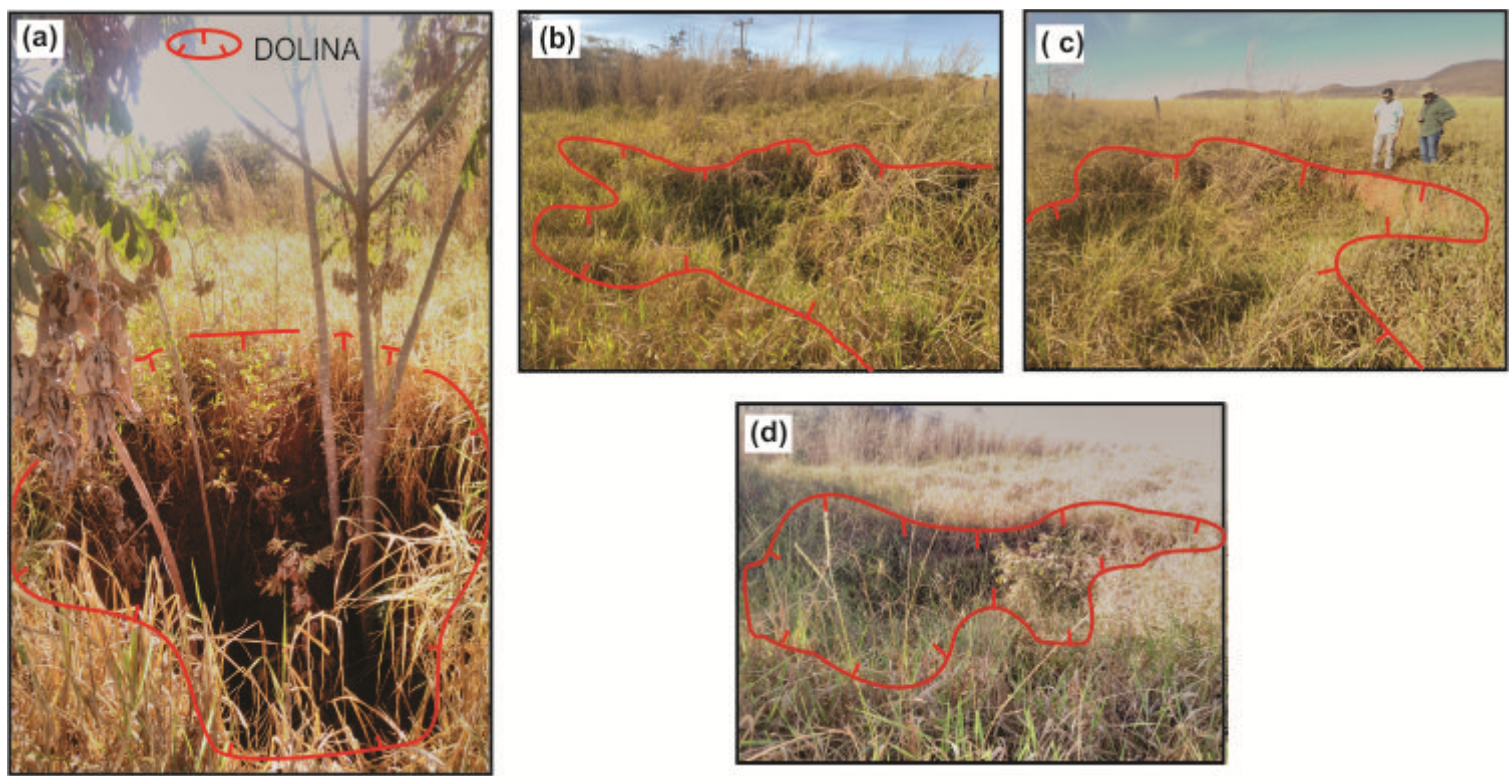

Figura 10: (a) Dolina de colapso em área de pastagem localizada no entorno da Latitude $12^{\circ} 12^{\prime} 8^{\prime \prime} \mathrm{S}$ e Longitude 46 59'29'W. (b), (c) e (d) Dolinas de dissolução em área de pasto nativo limpo, localizadas no entorno das coordenadas de Latitude $12^{\circ} 12^{\prime}$ '”'S e Longitude 46 59'29'W, Latitude $12^{\circ} 12^{\prime} 8^{\prime \prime}$ 'S e Longitude $46^{\circ} 59^{\prime} 29^{\prime} \mathrm{W}$ e Latitude $12^{\circ} 12^{\prime} 7^{\prime}$ 'S e Longitude 46 $59^{\prime} 29^{\prime} \mathrm{W}$, respectivamente. 
Dolinas de dissolução e de colapso também foram identificadas em área de transição entre a cidade de Taipas do Tocantins e sua zona rural. Em uma parcela da terra destinada à pastagem, foi possível constatar diversas dolinas dispostas uma ao lado da outra, com maior expressão latitudinal, o que permite inferir que a evolução dessas dolinas poderá no futuro vir a formar uma uvala (Figuras 10b, 10c e 10d).

No ano de 2017, a porcentagem da área destinada ao uso e cobertura da terra denominado florestas de fundo de vale e encostas (Veredas, Matas ciliares e Palmeirais) foi de 16,05\%, apresentando um pequeno declínio se comparado com os dados do ano de 1968, quando essa abrangia 16,75\% da área. A redução na área desse uso e cobertura da terra se vincula à pressão que as atividades antrópicas ao seu redor vêm exercendo sobre ela, sobretudo, das áreas de pastagem, conforme o observado na figura 11.

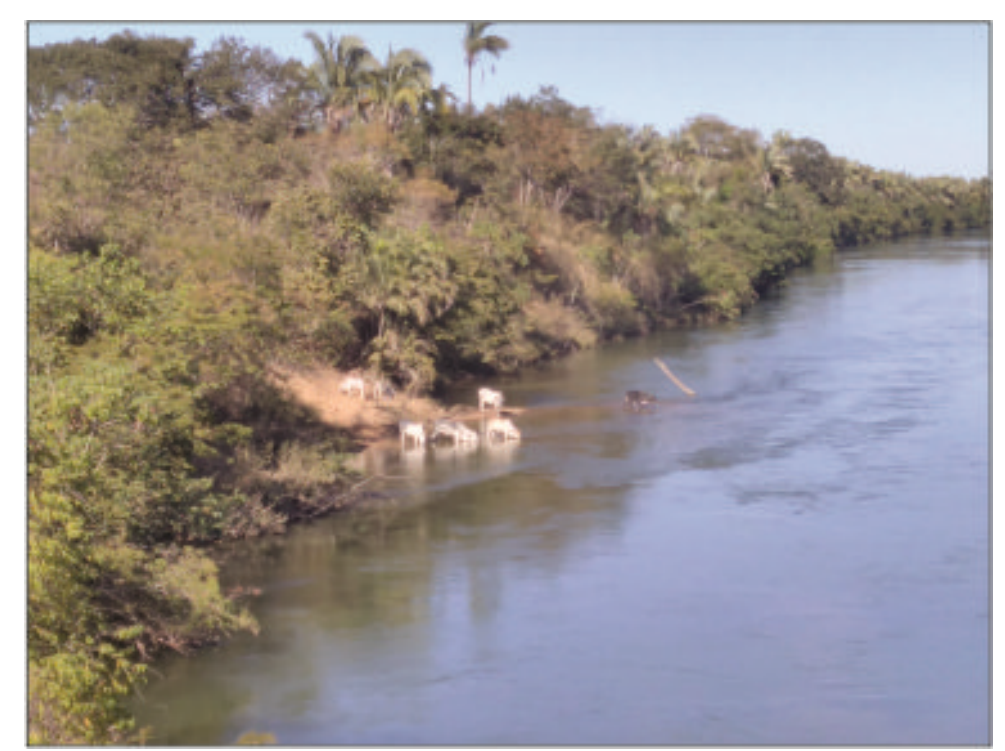

Figura 11: No centro da imagem, caminho de acesso do gado à água do rio Palmeiras entre a floresta de fundo de vale, com destaque para a mata ciliar e palmeirais.

Outro uso e cobertura da terra observado no ano de 2017, na porção nordeste do baixo curso do rio Palmeiras foi a silvicultura, que passou a ocupar $0,72 \%$ da área. A ação predatória do material lenhoso da vegetação original, para a produção de lenha usada, sobretudo, em caldeiras de cerâmicas, secagem dos grãos de soja, milho e milheto ou ainda em situações domiciliares, panificadoras e restaurantes, tem impactado severamente o Cerrado. Assim, a plantação de pinus (Figura 12) surge como uma tentativa de assegurar o suprimento de madeira de acordo com o aumento do ritmo da demanda.

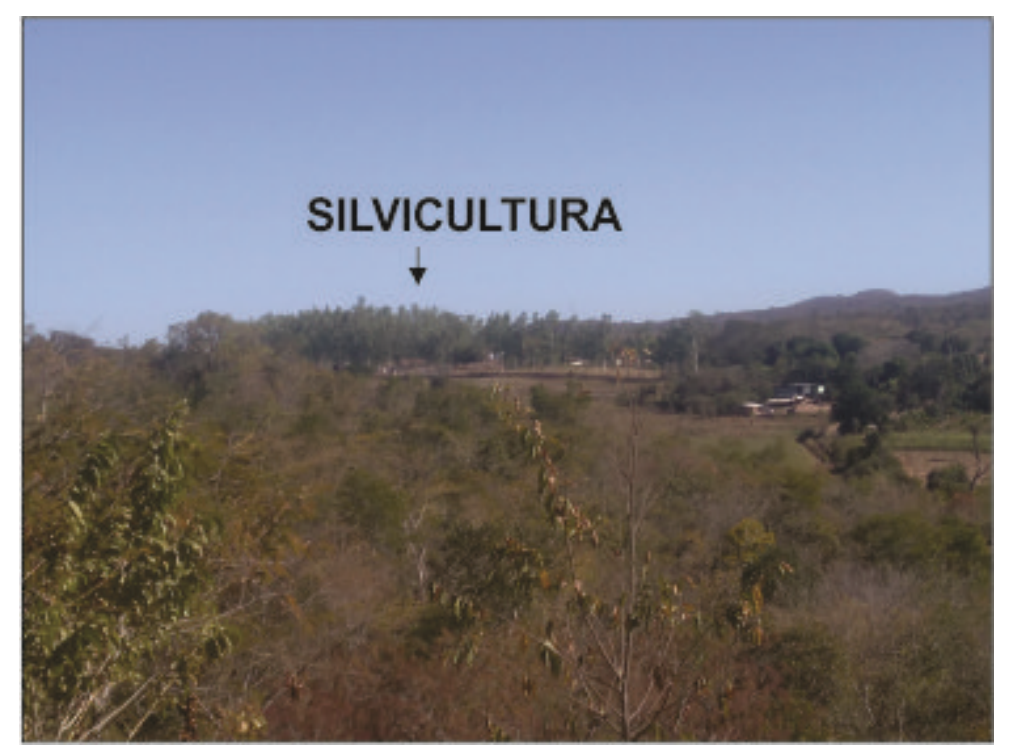

Figura 12: Área destinada à plantação de pinus para posterior queima da lenha. 
Face o aumento das atividades antrópicas, a área ocupada por residências urbanas e rurais, sobretudo no município de Taipas do Tocantins, passou a ocupar 0,25\% da área, no ano de 2017. Surgem também plantações de cultivos temporários, que passam a ocupar 1,6\% da área desse setor, com destaque para plantações de subsistência e a inserção do plantio da soja, do milho, do milheto e da cana de açúcar.

A classe de uso do solo identificada como solo exposto também apresentou aumento, passando a ocupar 0,62\% da área no ano de 2017, face os 0,46\% da área destinados a esse tipo de uso em 1968 (Figura 3). Essa classe de uso e cobertura da terra foi detectada próxima a áreas de lagoas, quando essas estão com pouca ou nenhuma água em época de estiagem, conforme observado na figura 6, em áreas onde, naturalmente, o solo é arenoso (Figura 13a), impossibilitando o desenvolvimento da vegetação, ou ainda em áreas desmatadas pela ação antrópica para a inserção de pastos ou do preparo do solo para o plantio (Figura 13b).
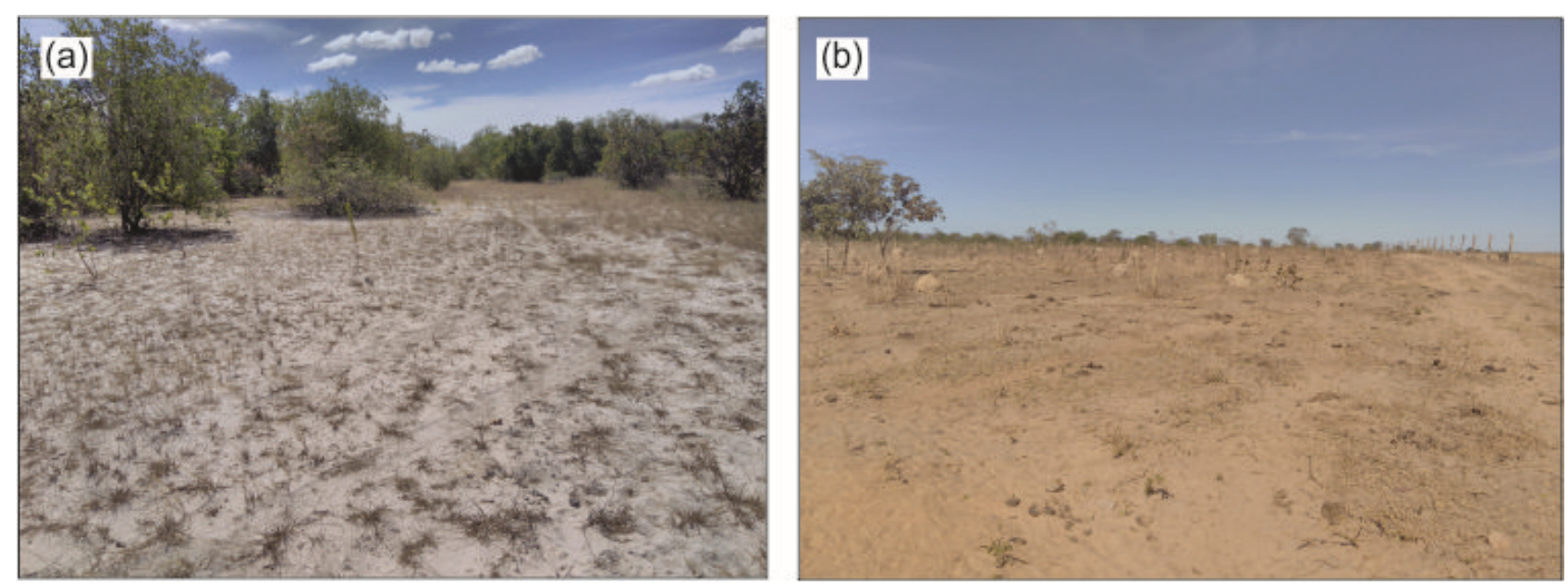

Figura 13: (a) Solos arenosos sobre os quais a vegetação tem dificuldade em se desenvolver, deixando-os expostos. (b) Solo exposto em terreno que teve a vegetação nativa retirada na tentativa de torná-lo área de pastagem, porém, devido ao sobrepastoreio, a vegetação não volta a nascer.

\section{Conclusões}

As discussões sobre o uso e cobertura da terra e sua dinâmica se pautam, principalmente, na análise das características observáveis da paisagem, fornecidas pelos mapeamentos de uso e cobertura da terra dos anos de 1968 e 2017, a partir do qual foi inferida a dinâmica do sistema socioeconômico juntamente com a revisão bibliográfica e trabalho de campo.

O mapa geomorfológico da área, do ano de 1968, na escala 1:25.000, mostrou-se eficaz para a análise da morfogênese do relevo. Esse tipo de mapeamento permite a compreensão da organização dos terrenos, embasando outras análises importantes no contexto da apropriação cada vez mais acelerada da terra pelo ser humano, como por exemplo, nas questões de análise de risco e do ordenamento territorial. O uso dessa escala se revelou demasiado pequena para a identificação de feições vinculadas ao carste, característico da área, porém, é uma contribuição importante para estudos na região, que no geral dispõem apenas de mapeamentos em escala menores.

As únicas fotografias aéreas existentes da região datam de 1968, o que impossibilitou a elaboração de mapeamentos geomorfológicos mais recentes. Desta forma, o trabalho de campo foi de fundamental importância para a identificação in loco da existência de formas vinculadas ao carste e para o entendimento de sua relação com o uso e cobertura da terra, que no geral, é destinado à pastagem, ou ainda se encontra encoberto por vegetação nativa. Além disso, o campo possibilitou a reambulação de classes de uso e cobertura da terra identificadas em fase laboratorial, com base nas imagens obtidas pelo satélite RapidEye no ano de 2014, adequando-o ao uso existente no ano de 2017.

A dinâmica do uso e cobertura da terra ocorrida no setor Sul da bacia hidrográfica do rio Palmeiras, no interior do estado do Tocantins, vincula-se diretamente às mudanças dos padrões socioeconômicos ocorridos na região, que ganhou destaque por se consolidar como a mais recente zona de expansão da fronteira pecuária e agrícola do país. Essa situação vem transformando por completo as características naturais da área. Assim, constatou-se considerável diminuição das áreas de vegetações nativas, vinculado ao bioma Cerrado, em função do aumento de áreas destinadas à pastagem, que ocorre de forma extensiva e em alguns setores, sobre relevos cársticos, que aos poucos vão sendo descaracterizados pelo sobrepastoreio. 
O acréscimo no número e áreas destinadas a represas e reservatórios artificiais também pode ser compreendido como efeito dessa mudança no perfil da área, de natural para agrária. Os resultados permitiram constatar alterações morfohidrográficas, com a construção de represas, aprofundamento do leito e alargamento da superfície de lagoas por meio do uso de maquinários, para aumentar a área de fornecimento de água para o gado no campo, além da construção de reservatório para o estabelecimento de uma Pequena Central Hidrelétrica, possibilitando o fornecimento de energia na região de acordo com a crescente demanda.

Assim, essa pesquisa possibilitou o fornecimento de parâmetros para um diagnóstico geral das alterações ocorridas na bacia hidrográfica do rio Palmeiras (TO), em escala de detalhe, os quais devem ser utilizados durante a elaboração de programas referentes ao planejamento e gestão ambiental na área.

\section{Agradecimentos}

Os autores agradecem ao Programa Nacional de Pós-Graduação (PNPD/CAPES) pelo suporte financeiro, bem como ao programa de Pós-Graduação da Universidade Federal de Tocantins, Campus Porto Nacional, pela infraestrutura disponibilizada no decorrer do desenvolvimento do trabalho.

\section{Referências}

BRASIL. Ministério do Meio Ambiente; IBAMA; Embrapa; INPE; UFG; UFU. Projeto TerraClass Cerrado. Mapeamento do Uso e Cobertura Vegetal do Cerrado. 2013, 23 p. Disponível em: 〈http://www.dpi.inpe.br/tccerrado/TCCerrado_2013.pdf $>$. Acesso em 11 de agosto de 2017.

CAMPOS, J. E. G.; DARDENNE, M. A. Origem e evolução tectônica da bacia Sanfranciscana. Revista Brasileira de Geociências, 27(3):283-294, setembro de 1997.

CASTRO, C. N. de.; A agropecuária na região norte: oportunidades e limitações ao desenvolvimento. Texto para discussão. Instituto de Pesquisa Econômica Aplicada (IPEA). Brasília: Rio de Janeiro: 2013. Disponível em 〈http://repositorio.ipea.gov.br/bitstream/11058/1215/1/TD 1836.pdf >. Acesso em 28 de Outubro de 2017.

EMBRAPA, Empresa Brasileira de Pesquisa Agropecuária. Palmeiral. Disponível em: $<$ http://www.agencia.cnptia.embrapa.br/Agencia16/AG01/arvore/AG01_51_911200585234.html>. Acesso em 10 de set. de 2017a.

EMBRAPA, Empresa Brasileira de Pesquisa Agropecuária. Vegetação Campestre. Disponível em: <http://www.agencia.cnptia.embrapa.br/Agencia16/AG01/arvore/AG01_45_911200585233.html>. Acesso em 10 de set. de 2017 b.

EMBRAPA, Empresa Brasileira de Pesquisa Agropecuária. Veredas. Disponível em: <http://www.agencia.cnptia.embrapa.br/Agencia16/AG01/arvore/AG01_45_911200585233.html>. Acesso em 10 de set. de $2017 \mathrm{c}$.

FURTADO, C. Formação econômica do Brasil. São Paulo, Companhia das letras, 34ª . ed., 2007, 351 p.

GIRARDI, E. P. Proposição teórico-metodológica de uma cartografia geográfica crítica e sua aplicação no desenvolvimento do atlas da questão agrária brasileira. UNESP. Tese de Doutorado, Presidente Prudente, 2008. Disponível em: 〈http://www2.fct.unesp.br/nera/atlas/downloads.htm>. Acesso em 28 de Agosto de 2017.

IBGE, Instituto Brasileiro De Geografia E Estatística. Manual técnico de uso da terra. 3 ed. Brasília: IBGE, 2013. 171 p. (Manuais Técnicos em Geociências, n. 7).

IBGE, Instituto Brasileiro De Geografia E Estatística. Produção agrícola por regiões no ano de 2014. Disponível em <http://www.brasil.gov.br/economia-e-emprego/2014/08/ibge.png/view>. Acesso em $17 \mathrm{de}$ Julho de 2018.

INPE, Instituto Nacional de Pesquisas Espaciais. Projeto Monitoramento Cerrado. Disponível em <http://www.obt.inpe.br/cerrado/>. Acesso em 05 de Março de 2018.

KARMANN, I., SANCHEZ, L.E. Distribuição das Rochas Carbonáticas e Províncias Espeleológicas do Brasil. Espeleo-Tema, n.13, p.105-167, 1979.

KIANG, C. H.; SILVA, F. P. Contribuição ao arcabouço geológico do sistema aquífero Urucuia. São Paulo, UNESP, Geociências, v. 34, n. 4, p.872-882, 2015. 
MORAIS, F. de. Caracterização geomorfológica da região de Aurora do Tocantins, Brasil. Revista Brasileira de Geomorfologia. v. 14, nº 2, 2013, p. 163-170.

PASCHOAL, L. G.; CONCEIÇÃO, F. T.; CUNHA, C. M. L. Utilização do ArcGis 9.3 na elaboração de simbologias para mapeamentos geomorfológicos: Uma aplicação na área do Complexo Argileiro de Santa Gertrudes/SP. 2010. In: VIII Simpósio Nacional de Geomorfologia. Recife: 2010, 13 p.

PASCHOAL, L. G.; MORAIS, F. Contribuição à avaliação da criação de simbologias para mapeamentos geomorfológicos sobre imagens anáglifos georreferenciadas em ambiente SIG. In: XVII Simpósio Brasileiro de Geografia Física Aplicada - SBGFA; I Congresso Nacional de Geografia Física. Campinas, SP: 2017.

PENTEADO, M. M. Fundamentos de geomorfologia. Rio de Janeiro: IBGE, 1978, 185 p.

PRADO JR., C. A revolução brasileira; A questão agrária no Brasil. São Paulo, Companhia das Letras, $1^{\text {a }}$. ed., 2014, 463 p.

PRADO JR., C. Formação do Brasil contemporâneo. 1ª. Ed. São Paulo, Companhia das Letras, 2011, 446 p.

RIBEIRO, J. F. \& WALTER, B. M. T. Fitofisionomias do Bioma Cerrado. In: S. M. Sano \& S. P. Almeida (eds.). Cerrado: ambiente e flora. Embrapa Cerrados, Planaltina, 1998, p. 87-166.

RODRIGUES, M. L.; CUNHA, L. RAMOS, C.; PEREIRA, A. R.; TELES, V. DIMUCCIO, L. Glossário ilustrado de termos cársicos. Lisboa: Colibri artes gráficas, 2007, 167 p.

SANTOS, A. I. C. dos. Análise dos procedimentos para implantação de Pequenas Centrais Hidrelétricas no estado de Tocantins: estudo de caso na bacia do rio Palmeiras. Dissertação de Mestrado. $116 \mathrm{f}$. Universidade Federal do Rio Grande do Sul, 2011.

SEPLAN - Secretaria do Planejamento e da Modernização da Gestão Pública. Atlas do Tocantins: subsídios ao planejamento da gestão territorial. Superintendência de Pesquisa e Zoneamento EcológicoEconômico. Diretoria de Zoneamento Ecológico-Econômico - DZE. Organizado e atualizado por Paulo Augusto Barros de Sousa, Rodrigo Sabino Teixeira Borges e Ricardo Ribeiro Dias. 6. ed. rev. atu. Palmas: Seplan, 2012. 80 p. Disponível em: 〈http://seplan.to.gov.br/zoneamento/atlas-do-tocantins/> Acesso em 27 de Agosto de 2017.

SILVA. F. F.; MORAIS F. Índice de perturbações ambientais em áreas cársticas do estado do Tocantins primeira aplicação no Brasil. Revista Brasileira de Geografia Física, v.09, n.03 (2016) 766-777.

SOUZA, T. A. de.; OLIVEIRA, R. C. Avaliação da potencialidade de imagens tridimensionais em meio digital para o mapeamento geomorfológico. Revista GeoNorte. Manaus/AM, Edição Especial, v.2, n.4, p.1348 - 1355, 2012.

TRICART, J. Principes et méthodes de la géomorphologie. Paris: Masson, 1965.

VERSTAPPEN, H. T.; ZUIDAN, R. A. van. ITC System of geomorphological survey. Manual ITC Textbook, Netherlands: Enschede, 1975, v. 1.

ZALÁN, P. V.; ROMEIRO-SILVA, P. C. Bacia do São Francisco. Boletim de Geociências da Petrobras. v. 15, n.2, p. 561-571. 2007. 